\title{
Research on Ideological and Political Education of Postgraduates Based on Culture Construction of College Sports
}

\author{
Jing Piao, a , Keyi Jin ${ }^{1, b^{*}}$ \\ ${ }^{1}$ Dalian Nationalities University, Dalian, 116622, China \\ ${ }^{2}$ Dalian University, Dalian, 116622, China \\ * Corresponding Author: Keyi Jin
}

Keywords: Ideological and political education, Sports culture construction, Physical education

\begin{abstract}
Ideological and political education in colleges and universities is an arduous task. Today, with the development of diversified culture, ideological and political education in colleges and universities is faced with great challenges. The formation and development of campus sports culture has gradually become an important medium and means to train students development. This paper analyzes the ways of carrying out the ideological and political education of college students through the material culture construction, spiritual culture construction and system culture construction of campus sports to provide some references for the relative researchers.
\end{abstract}

\section{Introduction}

Sports culture is a kind of culture created by human beings in the process of sports activities and sports practice, which can promote people's overall, harmonious and free development. The campus sports culture is rooted in the society, with the development of human society and development, so the campus sports culture inevitably affected all aspects of society, different campus sports culture under different social forms, which reflects the social characteristics of different. In sports activities, everyone is different from each other and reflects individual characteristics. Therefore, it is characterized by the unity of individuality and sociality. One of the most important forms of campus sports culture is competition. To distinguish between winning and losing, it is necessary to distinguish between matches. A competition is not only individual competition, but also the coordination of all aspects of cooperation. Therefore, cooperation and competition become the two independent and closely related characteristics of sports culture. Campus sports culture is the same. By participating in sports activities to achieve physical exercise, sublimation of thinking, edify sentiment, communication and communication, and distinguish the strength and strength, it is the embodiment of human culture of sports culture. It spans different ideologies and is a precious asset shared and shared by mankind. Sports culture also has educational function. With the development of human society, sports culture not only seals the historical mark, but also embodies the characteristics of the times. As the cradle of talents, knowledge of the campus, the main campus is not only a good product from traditional sports culture and absorb the essence, can be combined with modern new material, to create a new era of sports culture. Therefore, campus sports culture has the functions of belief cultivation, psychological guidance and emotional cultivation to promote the unity and promoting harmony.

\section{Important Functions of Sports Culture Construction for Ideological and Political Education}

Enhance Thought Cognition of Students. In the teaching of physical education in Colleges and universities, while imparting students' sports skills, they can also train students' collective spirit of 
loving their motherland and uniting and forging ahead. In the sports teaching penetration of Ideological and political education is a very important work, independent ability, continue to forge ahead in this process can be cultivated and good quality, therefore it needs unremittingly, the teachers should possess higher professional qualities, in sports teaching is not only to make the students master the basic sports knowledge and skills, but also be able to let the students sports knowledge and truth in life together, only teachers to improve their professional knowledge and ideological consciousness, penetration of the ideological and political education in the sports teaching can achieve better results. In college physical education, ideological and political education can help students set up a correct world outlook, outlook on life and values. Students not only learn relevant knowledge, but also have their own set of rules of survival on how to base themselves on society and how to behave. This is not only beneficial to the all-round development of students themselves, but also conducive to the rapid development of society. The long-term stability of society requires the care and care of every citizen. The most important thing is to have a sound mind and body. Students will inevitably make some mistakes during their study, which requires a patient education by their teachers. Through the combination of physical training and ideological education, it will be better for students to infiltrate the teaching effect of Ideological and political education.

Enhance Moral Attainments of Students. With its grand ceremony, sports bring the young students to the joy of success through cooperation and hard work, so that they will naturally have a sense of achievement and honor after their victory and success. Although the purpose of participation of students is different, the methods are different, but the joy of victory and the pain of failure, the quality of the will is to experience and get the correct value orientation. Intense competition, strong confrontation, so that students fully experience the hardships of success, but also deeply aware of the importance of teamwork. Sports itself has the strict organization and discipline, by promoting and advocating the spirit of fair competition and solidarity of the moral guidance, to cultivate students to form good moral character to help each other and dedicated team, through competition and cooperation, can help students to understand the impact of individual behavior on the collective, thus to cultivate students' collective honor sense. Students to participate in the team competition and confrontation, so that they can gain momentum and will meet the spiritual belief, exercise firm and indomitable spirit, thus greatly stimulate their positive desire. As for college students, it is very important for them to change their sports spirit into the motive force of study and work, and lay a good ideological realm. Whether a person can be patriotic, devoted to the party, dedicated, or respect for science and the pursuit of truth is essentially a question of whether a person's spiritual world is enriched or not. Therefore, the construction of campus sports culture is one of the important means for students' moral education.

Enhance Psychological Qualities of Students. In modern college students, there is an upward trend in psychological diseases, such as the pressure of employment, the pressure of study, the pressure of family difficulties, the pressure of making friends and so on, which makes the psychological pressure of college students too great. Therefore, how to reduce students' psychological burden is an important task for College Ideological and political workers to actively explore. Twenty-first Century will be an era full of competition and challenges. The country needs not only rich knowledge, strong sense of competition, good moral standards, but also need to be psychologically healthy. Sports is a healthy and civilized activity, with its unique content and form, enrich the students' spiritual life, and promote the interaction between students. Sports can enrich students' amateur cultural life, to enable students to cultivate the spirit obtained, get physical exercise, and learn the skills and training methods of sports in sports at the same time. Good psychological quality plays an important role in regulating the overall quality of human beings. It not only affects people's physiological skills, but also directly relates to the improvement of their abilities and qualities. Through many studies have shown that psychological quality is one of the key to success in business, actively participate in the activities of college students through the campus sports culture, promote their own psychological quality continuous improvement and perfection of personality, make yourself more brave, strong, decisive, bright and warm, put yourself completely into the 
collective. The improvement of these psychological qualities enables students to play a positive role in participating in campus sports and cultural activities.

\section{Reform Suggestions of Ideological and Political Education Based on Sports Culture Construction}

Permeation of Sports Material Culture in Ideological and Political Education. Sports buildings, stadiums, facilities, equipment, good or bad, not only can foil the campus sports culture environment, and let students enter the campus, be affected by the sports environment. Therefore, all colleges and universities should increase the input of funds, to make full use of campus space, reasonable layout of open good student activities facilities, improve the utilization of the facilities, the campus sports material culture provides a good educational space for the ideological and political education of College students. Sports material culture is the external symbol of campus sports culture, and is the basis and carrier for the survival and development of campus sports spiritual culture. It mainly includes sports venues and equipment, schools, the use of media to promote sports knowledge, sports environment and atmosphere. Campus sports material culture as the material carrier, its core connotation is the spiritual cultural factor. Therefore, the construction of sports material culture is not an end, but a means. The influence of sports material culture on the ideological and political education of college students is first manifested in its appearance, which can stimulate students' interest and enthusiasm, and enhance their sense of pride. The second is reflected in the practicality, the practical performance to meet the needs of students, enable students to enhance physical fitness in happy and pleased with oneself movement, improve sports skills, self-confidence. Thirdly, it is rich in imagination, which makes the students get aesthetic influence and personality infection. The investigation shows that the utilization rate of sports facilities in our universities is low. The whole sports propaganda facility is few, the propaganda way is unitary, the propaganda content and the propaganda effect can be imagined, which greatly affects the physical, cultural, outward appearance and practical educational effects of sports. It is good to know that the university sports teaching environment and the use of sports media, promotion and dissemination of sports knowledge, and enhance the students' attention to sports, and stimulate their enthusiasm for patriotism and national pride.

Permeation of Sports Spiritual Culture in Ideological and Political Education. The sports spirit culture has the stability once it has formed, and has promoted the school sports teaching and the campus sports culture positively. The spirit of sports can sublimate human spirit and make people's value be confirmed. Therefore, through the development of campus sports activities rich and colorful, the process can make students in the fight for the collective honor, dignity to experience as a member of the collective, harmonious interpersonal relationships, exercise teamwork spirit, inspire their enthusiasm and communicate their heart. At the same time, the patriotic spirit through the sports classroom, blackboard, Sports Salon, organized students to watch major sporting events and other publicity of sports, education of patriotism. Therefore, colleges and universities should make full use of sports events, influence and regulate students' thinking and behavior, and make campus sports spiritual culture provide a good atmosphere for college students' Ideological and political education. Sports concept is people's understanding of sports in fitness, entertainment, aesthetic, as well as in the psychological quality, moral, intellectual and other aspects of the value embodied in the attitude. College students have a positive attitude towards physical fitness and mood improvement, and most of them have not really realized the effect of sports on emotion regulation and personality. Campus sports spirit refers to the gradual accumulation, in the construction of campus sports culture in the long-term integration, refined, value concept and group consciousness reflects most teachers and students' fitness goals, ideals, beliefs, and behavior criterion of traditional sports. The result shows that most students can obey the rules consciously, obey the referee and respect each other. Sports morality is the concrete manifestation of students' internal consciousness, idea and value of sports.

Permeation of Sports System Culture in Ideological and Political Education. Sports system culture is formed and developed in the practice of physical education, and is fixed by the provisions. 
It has the basic characteristics of high science, generality and standardization. All schools have the written system in developed countries, but most schools do not according to their own situation to build the system, from the survey of relevant rules, athletes physical education teachers work rules, the campus sports civilization standard, reflect the gap of related system specific to the implementation, there are quite many people are not clearly, the relevant system is also difficult to really play its due role. Sports tradition is a kind of collective sports behavior which has been developed and inherited in a long time in sports activities, which is universal, repetitive and relatively stable. The traditional sports activities are still games for sports festival, the school also did not pay full attention, most schools have high level sports teams, that schools in high level sports team leading role in sports activities have certain understanding. Most schools do not set up special institutions for sports activities, lack of planning for sports activities, all of which greatly weaken the campus sports culture, ideological and political education function. The process of forming the system and obeying the system is essentially a process of cultural sedimentation, which is the main sign of the quality of teaching and the level of sports. Thinking and behavior of students with cultural system regulation, constraints, norms and guidance, it can guide students to carry out sports activities and competition in terms of rules to strengthen the moral cultivation. Therefore, all colleges and universities should make full use of the construction of sports culture system for college students' ideological and political education to create a standardized and orderly environment.

\section{Conclusion}

The construction of campus sports culture has played a great role in improving and improving ideological and political education. The core value system of campus sports culture construction is also in line with the needs of training qualified personnel in Ideological and political work. Through the continuous development of campus sports culture, gradually educate and train the students' interest in life, study and work, so that they can develop in a comprehensive way under the guidance of correct and healthy values.

\section{References}

[1] Hu Qiliang, Lan Zili, Wang Yunling. A Strategic Study of the Interaction between campus P. E. culture in Col leges and Universities and the Ideological and Political Education for Undergraduates [J]. Journal of Capital Instittue of Physical Education, 2010, 22(3): 70-73+89.

[2] Lian Tiantian. Study on the Effective Way of Infiltrating Ideological and PoliticalEducation in College Physical Education [J]. Journal of Pu'er University, 2016, 32(3): 50-52.

[3] Lu Haiying, Huang Yongliang. Influence on Phsical Education Curriculum Reform to innovation of Colleges and Universities Students Ideological and Political Education [J]. Zhejiang Sport Science, 2017, 39(2): 99-101.

[4] Hu Qiliang, Yan Xinping. Study on Ideological and Political Educati on Function of College Campus Sports Culture [J]. Bulletin of Sport Science \& Technology, 2011, 19(5): 9-10+13.

[5] Lian Zhining. Tentative Analysis of Implicit Ideological and Political Education Approaches in College Sports Associations [J]. Sports Science Research, 2014, 18(2): 89-92. 